\title{
Radioactivity levels in beach sand from the West Coast of Sri Lanka ${ }^{\dagger}$
}

\author{
P. Mahawatte ${ }^{1 *}$ and K.N.R. Fernando ${ }^{2}$ \\ ${ }^{1}$ Department of Nuclear Science, Faculty of Science, University of Colombo, Colombo 03. \\ ${ }^{2}$ Atomic Energy Authority, No. 60/460, Baseline Road, Orugodawatta, Wellampitiya.
}

\begin{abstract}
Concentration of primordial radionuclides in 48 sand samples collected from the coastal strip from Uswetakeyyawa to Chillaw in the West Coast of Sri Lanka was measured using a high purity germanium (HPGe) detector. The measured activity concentrations of ${ }^{232} \mathrm{Th}$ ranged from $14 \pm 3$ to $6257 \pm 38 \mathrm{~Bq} \mathrm{~kg}{ }^{-1}$. The maximum concentrations of ${ }^{238} \mathrm{U}$ and ${ }^{40} \mathrm{~K}$ measured were $1243 \pm 15$ and $647 \pm 37 \mathrm{~Bq} \mathrm{~kg}^{-1}$, respectively and the minimum were below the detection limits. The detection limits of ${ }^{238} \mathrm{U},{ }^{232} \mathrm{Th}$ and ${ }^{40} \mathrm{~K}$ were $1.70,2.37$ and $10.41 \mathrm{~Bq} \mathrm{~kg}^{-1}$, respectively. The calculated external annual effective dose rate at one meter aboveground ranged from 5 - $4567 \mathrm{nGyh}^{-1}$. More than $50 \%$ of the samples analysed showed radium equivalent activity concentrations above the limit $370 \mathrm{~Bq} \mathrm{~kg}^{-1}$, which is the value recommended for the safe use of building materials for dwellings. The same 48 samples were parallely analysed using $\mathrm{NaI}(\mathrm{Tl})$ scintillation spectrometry. For ${ }^{238} \mathrm{U}$ and ${ }^{232} \mathrm{Th}$ the mean ratios of the values obtained by the two methods were 1.0148 and 1.0018 , respectively. The findings of this study shows that scintillation spectrometry provides a cost effective method to measure $\mathrm{U}$ and $\mathrm{Th}$ in radioactive beach sand.
\end{abstract}

Keywords: Beach sand, detection limits, gamma ray spectrometry, high radiation background area, scintillation spectrometry, Sri Lanka.

\section{INTRODUCTION}

Beach sand is weather resistant remainders of geological formations, which may have come to the coast through transport by rivers and deposited in the beach by the action of waves and currents. The waves wash back the lighter grains leaving behind the heavier ones on the beach. These processes when repeated over millions of years create large deposits of heavy minerals on the beach where they get concentrated in localized spots and can be recognized from their dark colour.
The heavy mineral deposits on the beach are rich in valuable minerals such as zircon, ilmenite, garnet and monazite. Such deposits have been of economic value due to their extensive use in many purposes. Zircon is used in the ceramic industry for glazing items such as wall and floor tiles, tableware and sanitaryware. Ilmenite and rutile have a high demand in paint, paper and plastic industry. Monazite is one of the most important geological materials containing $\mathrm{Th}$ and $\mathrm{U}$, which are the main elements used as fuel in nuclear power plants.

Natural radioactivity levels of beach sand in many countries have been measured by many workers in the past. Gamma dose rates and the distribution of natural radioactivity of beach sand in two islands in Southern Brazil have been measured by Freitas and Alencar in 2004. Veiga et al. (2006) measured the ${ }^{40} \mathrm{~K},{ }^{226} \mathrm{Ra}$ and ${ }^{232} \mathrm{Th}$ in sand samples collected from 43 different tourist resorts in four Brazilian states. They have measured the activity concentrations in the sand samples using both $\mathrm{NaI}(\mathrm{Tl})$ and high purity Ge (HPGe) detector. The ${ }^{226} \mathrm{Ra},{ }^{232} \mathrm{Th}$ and ${ }^{40} \mathrm{~K}$ activities in beach sand minerals zircon, ilmenite, magnetite, garnet and rutile collected from the plant of the Beach Sand Exploitation Center and soils from the tourist zone in Cox's Bazar, Bangladesh have been measured by Alam et al. (1999) using gamma ray spectrometry, with the aim of estimating the radiation hazard and establishing a database for the radioactivity levels of the plant and the tourist area nearby. A similar study has been carried out by Mohanty et al. (2004) at Chhatrapur beach placer deposit in the Orissa State in the South Eastern Coast of India and found that the mineral monazite contained the highest amount of ${ }^{232} \mathrm{Th}$ and ${ }^{238} \mathrm{U}$ and was the major contributor to the radiation exposure

\footnotetext{
*Corresponding author (palee_m@yahoo.com)

† This paper is based on the work presented as three communications in the Annual Sessions of the Sri Lanka Association for the Advancement of Science in 2008 and 2009.
} 
in the area. Kannan et al. (2002) performed a systematic study of the distribution of natural radionuclides in soil and beach sand collected from terrestrial and coastal environment of Kalpakkam and determined the activity concentrations of primordial radionuclides such as ${ }^{238} \mathrm{U},{ }^{232} \mathrm{Th}$ and ${ }^{40} \mathrm{~K}$ and also the anthropogenic radionuclide ${ }^{137} \mathrm{Cs}$. They found that ${ }^{232} \mathrm{Th}$ is the main contributor to the total absorbed gamma dose rate in air in the beach areas in Kalpakkam.

Areas rich in heavy mineral sands have also been identified in Sri Lanka. The East Coast deposits in Pulmudei and Kokilai are the largest beach mineral sand deposits in Sri Lanka (Herath, 2008). In the West Coast, the beach for several miles north of the Kelani River is rich in ilmenite (Herath, 2008). Similar deposits have been found in Kalutara, Induruwa and Kaikawala. The measured background radiation levels in these areas are much higher than the normal values as thorium rich monazite is an invariable constituent of these beach sands. Radiation levels measured in these areas are comparable to those measured in other high radiation background areas in the world. A value as high as $2.25 \mathrm{mR} \mathrm{h}^{-1}$ has been measured in a location in the Southwest Coast of the country (Amarasiriwardena,1978). However, a systematic study to measure the activity levels in beach sand in these areas has still not been carried out. Such a study in these areas is important to estimate the radiation exposure to the public and also in locating previously unidentified mineral sand deposits.

The present study was initiated to measure the ${ }^{238} \mathrm{U},{ }^{232} \mathrm{Th}$ and ${ }^{40} \mathrm{~K}$ concentrations in the beach sand in the coastal stretch from Uswetakeyyawa to Chillaw in the West Coast of Sri Lanka. The activity concentrations of ${ }^{238} \mathrm{U},{ }^{232} \mathrm{Th}$ and ${ }^{40} \mathrm{~K}$ were measured using a HPGe detector. The measured values were compared with those obtained from a $\mathrm{NaI}(\mathrm{Tl})$ detector to study the possibility of using the low cost $\mathrm{NaI}(\mathrm{Tl})$ detector for similar analysis in the future. The external dose due to the radionuclides have been calculated and compared with the dose rates in another high background radiation area in the region. The suitability of using beach sand as a construction material with respect to radiation exposure was investigated using the radium equivalent activity of the samples collected.

\section{METHODS AND MATERIALS}

\section{Preparation of the samples}

Superficial beach sand samples from 48 locations along a $70 \mathrm{~km}$ coastal stretch in the Western Coast of Sri Lanka were collected. The first 26 samples were sampled at $1 \mathrm{~km}$ intervals and the remaining at a distance of $2 \mathrm{~km}$. The sampling distance was changed from $1 \mathrm{~km}$ to $2 \mathrm{~km}$ due to the difficulty of accessing the beach. The locations from which the samples were collected are shown in Figure 1. The background radiation level at $1 \mathrm{~m}$ height was recorded at each sampling point using a FAG $\mathrm{FH}_{40} \mathrm{~F}_{2}$ Survey Meter, which was calibrated by the Atomic Energy Authority of Sri Lanka.

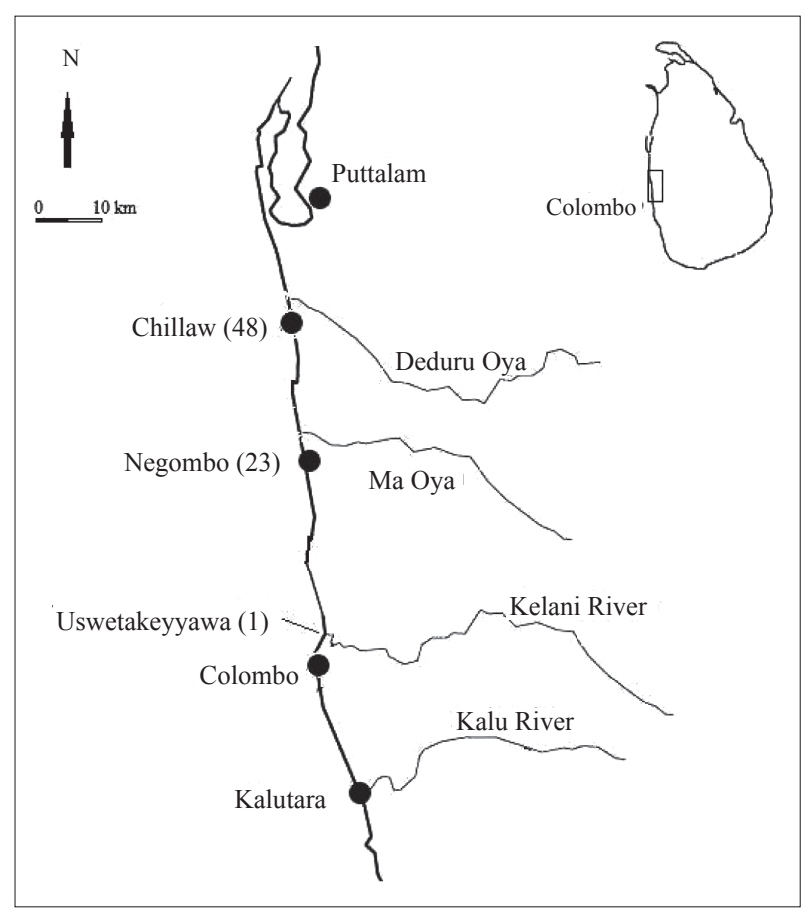

Figure 1: Map showing the sampling areas from Uswetakeyyawa to Negambo. The numbers given in parenthesis are the sample numbers at the respective location.

The samples were collected at each location by marking a square of $1 \times 1 \mathrm{~m}^{2}$, which was further divided into 16 equal squares. A sub-sample from the top $1 \mathrm{~cm}$ was scraped from the middle of each square and combined to make a gross sample of approximately $1 \mathrm{~kg}$ in weight from each sampling location. Immediately after collection, the sand was put into polythene bags, sealed, labelled and brought to the laboratory for analysis. The sample was first homogenized by hand mixing and then reduced to a smaller size by the coning and quartering method.

The samples were then washed thrice in tap water to remove sea water contamination and dried to a constant weight at $105{ }^{\circ} \mathrm{C}$. They were then sieved using a $0.25 \mathrm{~mm}$ mesh, packed and sealed in weighed cylindrical plastic containers of diameter $8.4 \mathrm{~cm}$ and height $2.9 \mathrm{~cm}$. The geometrical dimensions of the samples were kept identical to that of the reference materials. The sealed samples and the reference materials were stored for 3 wks before counting to allow ${ }^{226} \mathrm{Ra}$ to reach the secular equilibrium with their short lived decay products. 


\section{Gamma spectroscopy measurement}

The gamma spectroscopy measurements of the samples were carried out using a HPGe detector having a relative efficiency of $23 \%$ and an energy resolution of $1.85 \mathrm{keV}$ at $1.33 \mathrm{MeV}$ gamma line of ${ }^{60} \mathrm{Co}$. The detector was housed in a lead shield of thickness $10 \mathrm{~cm}$ with an inner surface cover of a $2 \mathrm{~mm}$ thick $\mathrm{Cu}$ sheet. The spectra were accumulated using Canberra S-100 MCA of 4096 channels. Each sample was counted for a period of $5000 \mathrm{~s}$. The background spectrum was obtained by counting an empty container for $10000 \mathrm{~s}$. The spectra were analyzed using the software package ANGAS developed by the International Atomic Energy Agency (IAEA). The system calibration was performed using 3 well-known reference materials RGU-1, RGTH-1 and RGK-1, which were also produced by the IAEA. The activities of ${ }^{238} \mathrm{U},{ }^{232} \mathrm{Th}$ and ${ }^{40} \mathrm{~K}$ were calculated by measuring the area under the photo peaks of energies $609 \mathrm{keV}\left({ }^{214} \mathrm{Bi}\right)$, $583 \mathrm{keV}\left({ }^{208} \mathrm{Tl}\right)$ and $1460 \mathrm{keV}\left({ }^{40} \mathrm{~K}\right)$, respectively. The secular equilibrium between ${ }^{238} \mathrm{U},{ }^{226} \mathrm{Ra}$ and its daughter products, and ${ }^{232}$ Th and its daughter products was assumed in all the calculations. The detection limits and the errors associated with the measurements were determined using the method described by Knoll (2000).

The counting system for $\mathrm{NaI}(\mathrm{Tl})$ detector comprised a 3" x 3" NaI (Tl) detector (Canberra Model 802-4), fast spectroscopy amplifier (Canberra Model 2024) and HV power supply (Canberra Model 3012). Canberra Series 35, MCA was used to accumulate the spectra. The NaI (Tl) detector was housed in a Pb shield of thickness $3 \mathrm{~cm}$. The same samples packed for counting in HPGe detector were used to count in the $\mathrm{NaI}(\mathrm{Tl})$ detector and the counts displayed under the 3 signature peaks in all spectra were noted. The windows of the signature peaks used for ${ }^{238} \mathrm{U}$, ${ }^{232} \mathrm{Th}$ and ${ }^{40} \mathrm{~K}$ were (1664 -1964 ), (2475 - 2805) and (1305-1588) keV, respectively. The 3 window matrix method described by Stromswold and Kosanke (1978) was used to calculate the ${ }^{238} \mathrm{U},{ }^{232} \mathrm{Th}$ and ${ }^{40} \mathrm{~K}$ activities of the samples. Matrix algebra was performed using MS Excel worksheet. The errors associated with the measurements and the detection limits were calculated using the method described by Chiozzi et al. (2000).

\section{Estimation of dose rates}

The absorbed dose rate in air at $1 \mathrm{~m}$ above ground was calculated using the following equation (UNSCEAR, 1993);

$$
\mathrm{D}\left(\mathrm{nGy} \mathrm{h}^{-1}\right)=0.0414 \mathrm{C}_{\mathrm{k}}+0.461 \mathrm{C}_{\mathrm{Ra}}+0.623 \mathrm{C}_{\mathrm{Th}}
$$

Where $\mathrm{C}_{\mathrm{K}}, \mathrm{C}_{\mathrm{Ra}}$ and $\mathrm{C}_{\mathrm{Th}}$ are activity concentrations of ${ }^{40} \mathrm{~K}$, ${ }^{226} \mathrm{Ra}$ and ${ }^{232} \mathrm{Th}$ in $\mathrm{Bq} \mathrm{kg}{ }^{-1}$, respectively. The effective dose was calculated by using the conversion coefficient of $0.72 \mathrm{~Sv} \mathrm{~Gy}^{-1}$ (UNSCEAR, 1993). The external annual effective dose was derived by assuming that a person spends 24 hrs per day, 365 days per year at the location where the samples were collected.

\section{Radium equivalent activity}

Radium equivalent activity is an index that has been introduced to represent the specific activities of ${ }^{226} \mathrm{Ra},{ }^{232} \mathrm{Th}$ and ${ }^{40} \mathrm{~K}$ by a single quantity, that takes into account the radiation hazard associated with them. This is related to the external gamma dose and internal dose due to radon and its daughters. For safe use of a building material, this quantity should be less than $370 \mathrm{~Bq} \mathrm{~kg}^{-1}$ (OECD, 1979). Since the beach sand is sometimes used as a construction material for buildings the radium equivalent activity of the beach sand was calculated using the following equation given by Beretka and Mathew (1985);

$$
\mathrm{Ra}_{\mathrm{eq}}=\mathrm{C}_{\mathrm{Ra}}+1.43 \mathrm{C}_{\mathrm{Th}}+0.077 \mathrm{C}_{\mathrm{k}}
$$

\section{RESULTS AND DISCUSSION}

The activity concentrations of ${ }^{238} \mathrm{U},{ }^{232} \mathrm{Th}$ and ${ }^{40} \mathrm{~K}$ of beach sand and the dose rates measured at all sampling locations are shown in Table 1. The measured activity concentration of ${ }^{232} \mathrm{Th}$ ranged from $14 \pm 3$ to $6257 \pm 38 \mathrm{~Bq} \mathrm{~kg}^{-1}$. Sample number 16, which was collected from Kapumgoda showed the maximum activity concentration for both ${ }^{238} \mathrm{U}$ and ${ }^{232} \mathrm{Th}$. The highest activity concentrations of ${ }^{238} \mathrm{U}$ and ${ }^{40} \mathrm{~K}$ measured were $1243 \pm 15$ and $647 \pm 37 \mathrm{~Bq} \mathrm{~kg}^{-1}$, respectirely. For ${ }^{238} \mathrm{U}$, five samples showed activity concentrations below the detection limit and for ${ }^{40} \mathrm{~K}$ only one sample showed activity concentration below the detection limit. The detection limits of ${ }^{238} \mathrm{U},{ }^{232} \mathrm{Th}$ and ${ }^{40} \mathrm{~K}$ were $1.70,2.37$ and $10.41 \mathrm{~Bq} \mathrm{~kg}^{-1}$, respectively. The correlation between the measured activity concentrations of ${ }^{238} \mathrm{U}$ and ${ }^{232} \mathrm{Th}$ is shown in Figure 2. A good correlation is seen with $r^{2}$ value of 0.9402 . The average ratio between the ${ }^{238} \mathrm{U}$ and ${ }^{232} \mathrm{Th}$ activity concentration is $0.2011 .{ }^{40} \mathrm{~K}$ is not correlated with any other radionuclide.

Large variations in the activity concentrations in locations within a distance of a few kilometres can be seen. The accumulation of active sand in these locations may be due to the variation of the topography of the underlying seabed in the local vicinity. 
Table 1: Activity concentrations of ${ }^{232} \mathrm{Th},{ }^{238} \mathrm{U}$ and ${ }^{40} \mathrm{~K}$ and the effective dose rates measured at the sampling points at one meter height. The uncertainty in radiation level measurement is $25 \%$.

\begin{tabular}{|c|c|c|c|c|c|}
\hline \multirow{2}{*}{$\begin{array}{l}\text { Sample } \\
\text { Number }\end{array}$} & \multirow[t]{2}{*}{ Location } & \multicolumn{3}{|c|}{ Activity concentration $\left(\mathrm{Bq} \mathrm{kg}{ }^{-1}\right)$} & \multirow{2}{*}{$\begin{array}{c}\text { Radiation } \\
\text { level } \\
\left(\mu \mathrm{Sv} \mathrm{h}^{-1}\right)\end{array}$} \\
\hline & & ${ }^{232} \mathrm{Th}$ & ${ }^{238} \mathrm{U}$ & ${ }^{40} \mathrm{~K}$ & \\
\hline 1 & Uswetakeyyawa 1 & $5207 \pm 37$ & $994 \pm 14$ & $647 \pm 37$ & 1.20 \\
\hline 2 & Uswetakeyyawa 2 & $5267 \pm 36$ & $986 \pm 14$ & $625 \pm 35$ & 2.40 \\
\hline 3 & Uswetakeyyawa 3 & $1494 \pm 21$ & $400 \pm 10$ & $373 \pm 30$ & 0.42 \\
\hline 4 & Uswetakeyyawa 4 & $564 \pm 15$ & $372 \pm 11$ & $189 \pm 24$ & 0.42 \\
\hline 5 & Uswetakeyyawa 5 & $243 \pm 9$ & $156 \pm 6$ & $170 \pm 22$ & 0.28 \\
\hline 6 & Thaldiyawatta 1 & $380 \pm 12$ & $126 \pm 6$ & $300 \pm 31$ & 0.42 \\
\hline 7 & Thaldiyawatta 2 & $3261 \pm 28$ & $781 \pm 12$ & $514 \pm 31$ & 1.58 \\
\hline 8 & Thaldiyawatta 3 & $1137 \pm 19$ & $359 \pm 9$ & $304 \pm 27$ & 0.72 \\
\hline 9 & Parana Ambalama 1 & $351 \pm 12$ & $106 \pm 6$ & $338 \pm 33$ & 0.23 \\
\hline 10 & Parana Ambalama 2 & $2805 \pm 27$ & $674 \pm 12$ & $350 \pm 27$ & 1.60 \\
\hline 11 & Appamulla 1 & $1168 \pm 18$ & $404 \pm 9$ & $311 \pm 27$ & 1.30 \\
\hline 12 & Appamulla 2 & $1944 \pm 23$ & $512 \pm 10$ & $305 \pm 26$ & 0.32 \\
\hline 13 & Elenagoda & $609 \pm 14$ & $235 \pm 8$ & LDL & 0.62 \\
\hline 14 & Peramungama & $840 \pm 15$ & $335 \pm 8$ & $220 \pm 22$ & 0.52 \\
\hline 15 & Sarakkuwa & $351 \pm 11$ & $111 \pm 6$ & $223 \pm 26$ & 0.48 \\
\hline 16 & Kapumgoda & $6257 \pm 38$ & $1243 \pm 15$ & $644 \pm 23$ & 3.20 \\
\hline 17 & Seththappaduwa & $4292 \pm 31$ & $882 \pm 12$ & $606 \pm 33$ & 1.90 \\
\hline 18 & Dungalapitiya & $512 \pm 12$ & $312 \pm 8$ & $200 \pm 21$ & 0.68 \\
\hline 19 & Thalahena 1 & $1066 \pm 17$ & $399 \pm 9$ & $211 \pm 21$ & 0.85 \\
\hline 20 & Thalahena 2 & $473 \pm 12$ & $246 \pm 8$ & $241 \pm 25$ & 0.32 \\
\hline 21 & Aluthkuruwa & $606 \pm 13$ & $340 \pm 8$ & $217 \pm 22$ & 0.48 \\
\hline 22 & Pitipana & $3415 \pm 29$ & $942 \pm 13$ & $486 \pm 31$ & 0.39 \\
\hline 23 & Negambo & $196 \pm 9$ & $84 \pm 5$ & $211 \pm 26$ & 0.20 \\
\hline 24 & Kudapaduwa & $183 \pm 8$ & $79 \pm 5$ & $197 \pm 24$ & 0.30 \\
\hline 25 & Palagathure 1 & $23 \pm 3$ & $10 \pm 2$ & $250 \pm 29$ & 0.28 \\
\hline 26 & Palagathure 2 & $27 \pm 3$ & $13 \pm 2$ & $333 \pm 33$ & 0.28 \\
\hline 27 & Sindaththiriya & $674 \pm 20$ & $204 \pm 10$ & $389 \pm 42$ & 0.45 \\
\hline 28 & Nainamadama West & $45 \pm 6$ & $23 \pm 4$ & $262 \pm 39$ & 0.24 \\
\hline 29 & Dummaladeniya West & $130 \pm 10$ & $30 \pm 4$ & $367 \pm 45$ & 0.24 \\
\hline 30 & Ullatiyawa & $18 \pm 4$ & $7 \pm 2$ & $359 \pm 64$ & 0.24 \\
\hline 31 & Kolinjadiya & $18 \pm 4$ & $20 \pm 3$ & $265 \pm 39$ & 0.24 \\
\hline 32 & Katuneriya & $53 \pm 6$ & $26 \pm 4$ & $243 \pm 37$ & 0.24 \\
\hline 33 & Mudukatuwa & $73 \pm 7$ & $22 \pm 4$ & $343 \pm 45$ & 0.24 \\
\hline 34 & Marawila & $26 \pm 4$ & $16 \pm 3$ & $231 \pm 36$ & 0.24 \\
\hline 35 & Modarawalla & $23 \pm 4$ & LDL & $352 \pm 44$ & 0.24 \\
\hline 36 & Thalwila & $14 \pm 3$ & LDL & $383 \pm 46$ & 0.24 \\
\hline 37 & Barudelpola & $31 \pm 5$ & $10 \pm 2$ & $445 \pm 51$ & 0.24 \\
\hline 38 & Toduwawa & $75 \pm 7$ & $21 \pm 3$ & $342 \pm 44$ & 0.24 \\
\hline 39 & Thoduwawa west & $51 \pm 6$ & $17 \pm 3$ & $409 \pm 50$ & 0.24 \\
\hline 40 & Iranawilla & $72 \pm 8$ & LDL & $309 \pm 46$ & 0.24 \\
\hline 41 & Abakdawila 1 & $72 \pm 8$ & LDL & $257 \pm 41$ & 0.24 \\
\hline 42 & Abakdawila 2 & $32 \pm 5$ & $14 \pm 3$ & $332 \pm 48$ & 0.24 \\
\hline 43 & Maduwatta & $74 \pm 8$ & LDL & $345 \pm 46$ & 0.24 \\
\hline 44 & Suduwalla & $342 \pm 17$ & $99 \pm 8$ & $291 \pm 43$ & 0.39 \\
\hline 45 & Chillaw & $112 \pm 10$ & $47 \pm 5$ & $353 \pm 48$ & 0.26 \\
\hline 46 & Chillaw ( Moyakata 1) & $1449 \pm 30$ & $350 \pm 13$ & $320 \pm 39$ & 0.35 \\
\hline 47 & Chillaw ( Moyakata 2) & $2711 \pm 40$ & $596 \pm 17$ & $385 \pm 43$ & 0.41 \\
\hline 48 & Chillaw & $764 \pm 22$ & $246 \pm 11$ & $275 \pm 47$ & 0.38 \\
\hline
\end{tabular}

LDL- less than detection limit 


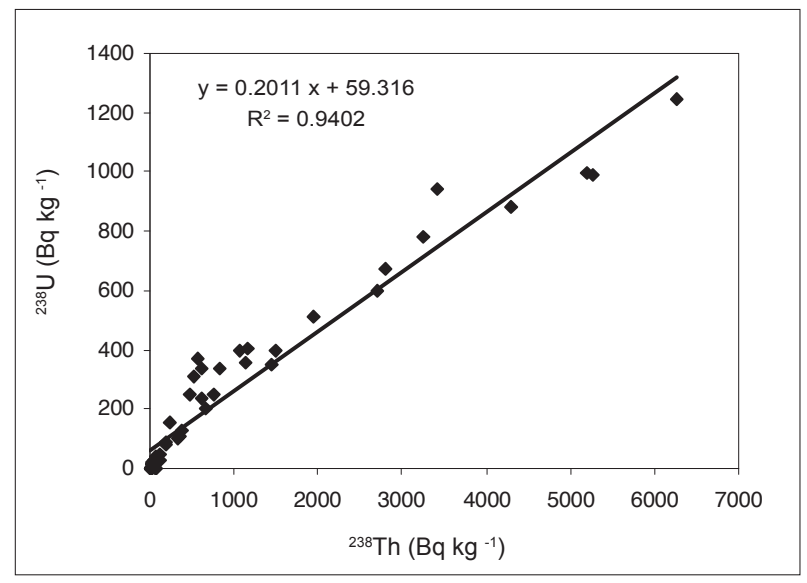

Figure 2: Correlation between ${ }^{238} \mathrm{U}$ and ${ }^{232} \mathrm{Th}$ activity concentrations
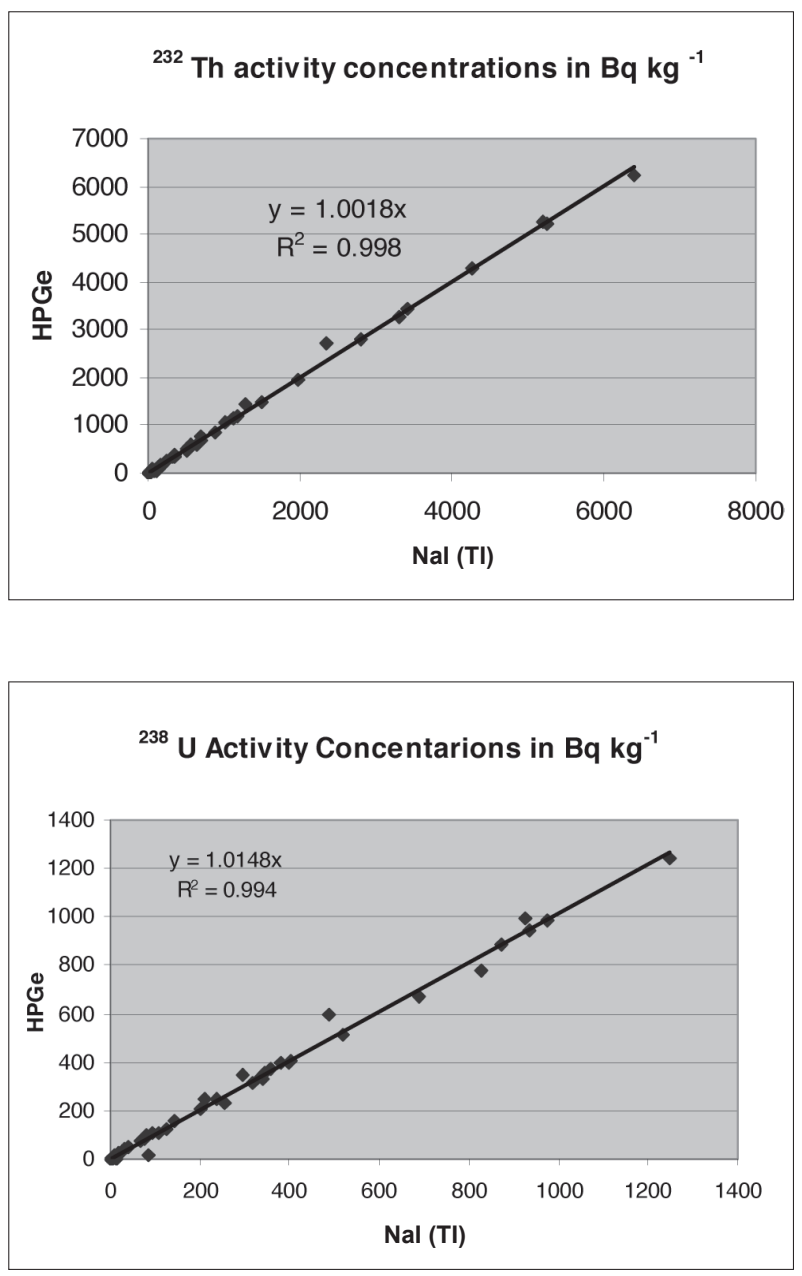

Figure 3: Correlation between the activity concentrations of ${ }^{232} \mathrm{Th}$ and ${ }^{238} \mathrm{U}$ measured by the two detectors.
The specific activities obtained with the $\mathrm{NaI}(\mathrm{Tl})$ detector as a function of the activities measured with the HPGe detector are shown in Figure 3. For both ${ }^{238} \mathrm{U}$ and ${ }^{232} \mathrm{Th}$, a good agreement between the values measured by the two methods can be seen. The gradient of the graphs of the measured values of ${ }^{238} \mathrm{U}$ and ${ }^{232} \mathrm{Th}$ were 1.0148 and 1.0018 , respectively. The $\mathrm{r}^{2}$ values for the measurements obtained by the two methods were 0.994 and 0.998 , respectively. For ${ }^{40} \mathrm{~K}$ the two methods could not be compared as the counting time was not long enough to get accurate results due to the high background count in the region of interest of the signature peak of ${ }^{40} \mathrm{~K}$. This is due to the high concentrations of ${ }^{238} \mathrm{U}$ and ${ }^{232} \mathrm{Th}$ in the samples. The calculated detection limits of ${ }^{238} \mathrm{U}$, ${ }^{232} \mathrm{Th}$ and ${ }^{40} \mathrm{~K}$ using the $\mathrm{NaI}(\mathrm{Tl})$ detector were 22, 21 and $90 \mathrm{~Bq} \mathrm{~kg}^{-1}$, respectively.

The calculated annual effective doses are shown in Figure 4. Twenty one of the 48 locations studied show annual effective doses above the world average of $2.4 \mathrm{mSv}^{-1}$ and the calculated absorbed dose rates range from 5 - $4567 \mathrm{nGy} \mathrm{h}^{-1}$. According to UNSCEAR (2000), the absorbed dose rates in air in the monazite bearing sand in the coastal areas in Kerala and Madras ranged from $200-4000 \mathrm{nGy} \mathrm{h}^{-1}$. In this study two locations with dose rates higher than that was reported in Kerala has been identified. The measured effective dose rates as a function of the calculated effective dose rates are shown in Figure 5. Most of the calculated effective dose rates agree with the measured values. However in some locations, a significant difference between the measured and calculated dose rates can be seen. This may be due to the fact that the calculated dose rate is based on the superficial sample collected, whereas the measured dose rate would account for any radiation level from greater depths.

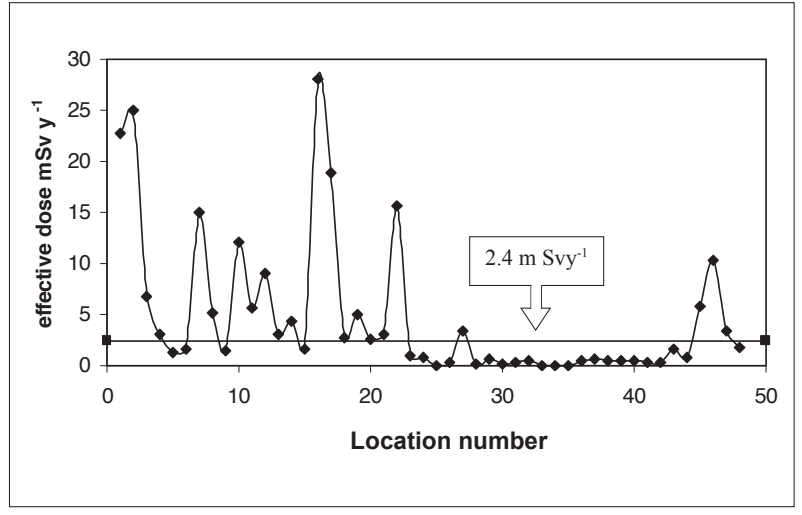

Figure 4: The calculated annual effective doses at the 48 sites studied in this work. 


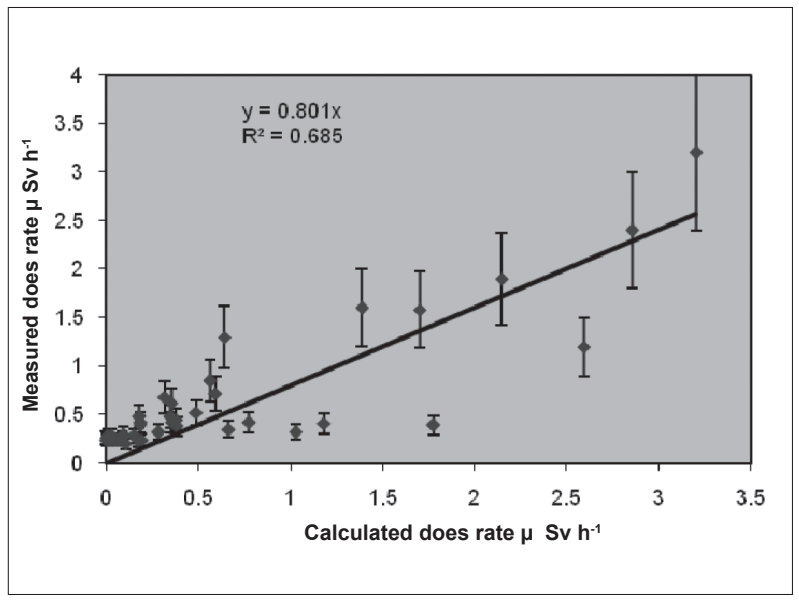

Figure 5: Measured dose rates as a function of the calculated dose rates in $\mu \mathrm{Sv} \mathrm{h}^{-1}$

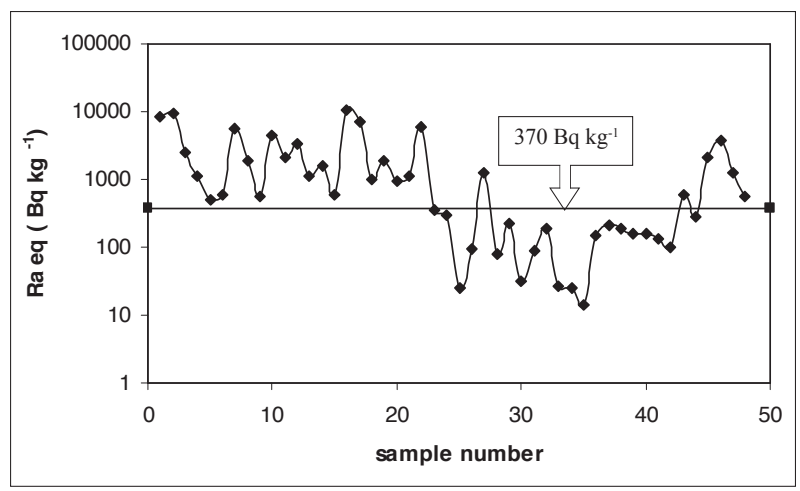

Figure 6: The specific radium equivalent activities of the sand in $\mathrm{Bq} \mathrm{kg}{ }^{-1}$.

The specific radium equivalent activity concentration calculated using the activity concentrations of ${ }^{40} \mathrm{~K},{ }^{238} \mathrm{U}$ and ${ }^{232} \mathrm{Th}$ are shown in Figure 6. It is observed that out of the 48 samples studied 28 had radium equivalent activity concentrations higher than $370 \mathrm{~Bq} \mathrm{~kg}{ }^{-1}$, which makes them unsuitable with respect to radiation exposure for use in building constructions. The sand samples that contained a higher amount of radioactivity were much heavier and could be visually identified by the presence of black coloured sand particles.

The use of beach sand for construction purposes can be a suitable alternative to overcome the heavy environmental degradation caused by mining river sand. However, the results of this study indicate the importance of testing the sand for radiological safety, when using for construction of dwellings.

\section{CONCLUSION}

The results of this work demonstrated the usefulness of the traditional inexpensive $\mathrm{NaI}(\mathrm{Tl})$ detector for ${ }^{238} \mathrm{U}$ and ${ }^{232} \mathrm{Th}$ analysis of beach sand. High concentration of ${ }^{232} \mathrm{Th}$ and ${ }^{238} \mathrm{U}$ was observed in sand at a previously unidentified location called Kapumgoda. The external effective dose rates observed in this study were comparable to the values measured in high radiation areas in the world and more than $50 \%$ of the sand samples analyzed in this study proved unsuitable for use in building construction.

\section{REFERENCES}

1. Alam M.N., Chowdhury M.I., Kamal M., Ghose S., Islam M.N., Mustafa M.N., Miah M.M.H. \& Ansary M.M. (1999). The ${ }^{226} \mathrm{Ra},{ }^{232} \mathrm{Th}$ and ${ }^{40} \mathrm{~K}$ activities in beach sand minerals and beach soils of Cox's Bazar, Bangladesh. Journal of Environmental Radioactivity 46: 243 - 250.

2. Amarasiriwardena D. (1978). Studies on environmental radioactivity in Sri Lanka. $M$ Phil thesis, University of Colombo, Colombo.

3. Beretka J. \& Mathew P.Y. (1985). Natural Radioactivity of Australian building materials, industrial wastes and by products. Health Physics 48(1): 87 - 95.

DOI: http://dx.doi.org/10.1097/00004032-198501000-00007

4. Chiozzi P., De Felice P., Fazio A., Pasquale V. \& Verdoya M. (2000). Laboratory application of $\mathrm{NaI}(\mathrm{TI})$ $\gamma$-ray spectrometry to studies of natural radioactivity in geophysics. Applied Radiation and Isotopes 53: $127-132$.

5. Freitas A.C. \& Alencar A.S. (2004). Gamma dose rates and distribution of natural radionuclides in and beaches-Ilha Grande, Southeastern Brazil. Journal of Environmental Radioactivity 75: 211 - 223.

DOI: http://dx.doi.org/10.1016/j.jenvrad.2004.01.002

6. Herath M.M.J.W. (2008). Beach Mineral Sands in Sri Lanka. Occurrence, Global Trends and Current Issues. Geological Survey and Mines Bureau, Colombo.

7. Kannan V., Rajan M.P., Iyengar M.A.R. \& Ramesh R. (2002). Distribution of natural and anthropogenic radionuclides in soil and beach sand samples of Kalpakkam (India) using hyper pure germanium (HPGe) gamma ray spectrometry. Applied Radiation and Isotopes 57: 109 - 119.

8. Knoll G.F. (2000). Radiation Detection and Measurements, $3^{\text {rd }}$ edition. John Wiley and Sons Inc. New York, USA.

9. Mohanty A.K., Sengupta D., Das S.K., Saha S.K. \& Van K.V. (2004). Natural radioactivity and radiation exposure in the high background area at Chhatrapur beach placer deposit of Orissa, India. Journal of Environmental Radioactivity 75: 15 - 33.

DOI: http://dx.doi.org/10.1016/j.jenvrad.2003.09.004

10. Organisation for Economic Cooperation and Development (OECD) (1979). Exposure to Radiation from Natural Radioactivity in Building 
Materials. Report by a Nuclear Energy Agency group of experts. Organisation for Economic Cooperation and Development, Paris, France.

11. Stromswold D.C. \& Kosanke K.L. (1978). Calibration and error analysis for spectral radiation detectors. IEEE Transactions on Nuclear Science 25(1): 782 - 785. DOI: http://dx.doi.org/10.1109/TNS.1978.4329409

12. United Nations Scientific Committee on the Effects of Ionizing Radiation (UNSCEAR) (1993). Sources and Effects of Ionizing Radiation. United Nations Scientific Committee on the Effects of Ionizing Radiation, United Nations, New York, USA.
13. United Nations Scientific Committee on the Effects of Ionizing Radiation (UNSCEAR) (2000). Sources and Effects of Ionizing Radiation. United Nations Scientific Committee on the Effects of Ionizing Radiation, United Nations, New York, USA.

14. Veiga R., Sanches N., Anjos R.M., Macario K., Bastos J., Iguatemy M., Aguiar J.G., Santos A.M.A., Mosquera B., Carvalho C., Baptista Filho M. \& Umisedo N.K. (2006). Measurement of natural radioactivity in Brazilian beach sands. Radiation Measurements 41: 189 - 196.

DOI: http://dx.doi.org/10.1016/j.radmeas.2005.05.001 